\title{
Invertebrates in overlooked aquatic ecosystem in the middle of the town
}

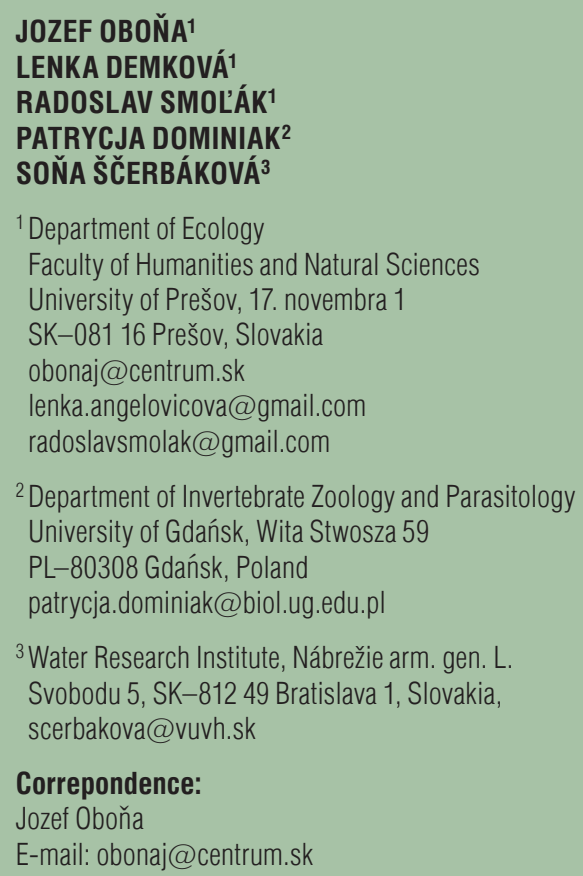

${ }^{3}$ Water Research Institute, Nábrežie arm. gen. L. Svobodu 5, SK-812 49 Bratislava 1, Slovakia, scerbakova@vuvh.sk

\section{Correpondence:}

Jozef Oboňa

E-mail: obonaj@centrum.sk

Key words: fountains, anthrotelmata, zoobenthos, zooplankton, Central Europe

Received April 27, 2016

Revised October 18, 2016

Accepted March 24, 2017

\section{Abstract}

Background and Purpose: Fountains are common, but usually overlooked anthrotelmata. To date, little attention has been paid to these ecosystems. This study reveals the first, more comprehensive evidence about seasonal changes of fauna in urban fountains and their insect and non-insect biodiversity.

Materials and Methods: The biodiversity of aquatic organisms from 6 fountains in the city center of Prešov (Eastern Slovakia) were studied and basic environmental characteristics, such as $\mathrm{pH}$, temperature, oxygen saturation and conductivity were measured during 2014. Water depth of studied fountains varied between $10-30 \mathrm{~cm}$ and water volume from 1.9 to $51 \mathrm{~m}^{3}$. For statistical evaluation nonparametric analyses were used.

Results and Conclusion: In total, over 66 taxa of the systematic groups Rotifera, Nematoda and Arthropoda were found. The most abundant insect group was Diptera. Zavrelimyia nubila (Diptera: Chironomidae) was recorded in Slovakia for the first time. Relative abundance of the evaluated insect taxa differed depending on the sampling date, and by water characteristics. Water volume and depth correlated negatively, but not signifcantly with relative abundance of all evaluated insect groups. Water $p H$ showed positive significant correlation with relative abundance of beetles, and negative, but not significant, correlation with the relative abundance of flies and mayflies.

\section{INTRODUCTION}

U rban fountains are in general basins or ponds with sprinkling water or anthrotelmata (sing. anthrotelma) - a wide variety of small, temporary water habitats artificially created as a result of human activities (1). Fountains are widely distributed and frequently visited spots in urban areas with historical, esthetical and sanitary function (2). Beside human usage fountains are widely exploited as a water source for birds and other vertebrate and invertebrate taxa. They are often used also by dispersing aquatic insects as a temporary shelter (3). Fountains, as indicated by Smolák et al. (3) are common urban anthrotelmata and can be utilized as breeding sites of epidemiologically significant mosquitoes, and could serve as ideal model systems for studies of island biogeography, colonization dynamics, assembly rules and other ecological topics. Urban fountains could play an important role in the spreading of epidemiologically significant species, e.g. in such habitat in Switzerland, Schaffner et al. (4) found invasive mosquito Aedes japonicus (Theobald, 1901). Hamerlík (5), Hamerlík \& Brodersen (6) and Bukvová \& Hamerlík (7) present a number of records concerning fountains, 


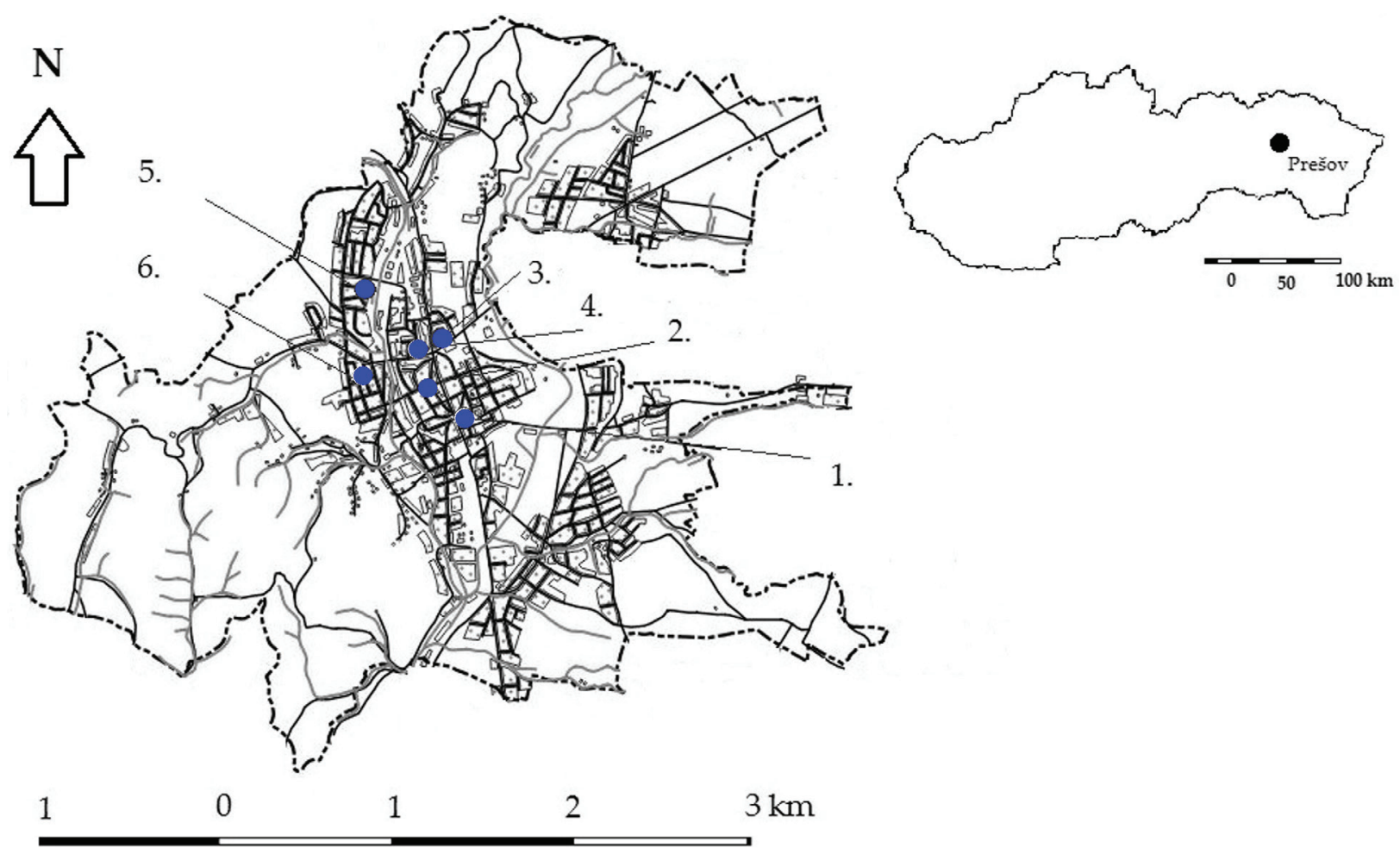

Figure 1. Map shows Slovakia with studied area (right) and sampling site in Prešov town (left; list of sampled sites in Table 1.)

including the first records of well-known chironomid fauna of Denmark and the Czech Republic. However, except Chironomidae, little attention was paid to European urban fountains, their potentially epidemiological significance and their ecological survey.

The main objective of this study is to find first more comprehensive evidence about these overlooked aquatic urban ecosystems and their insect and non-insect biodiversity. Secondary purposes are to describe seasonal changes of fauna in urban fountains and to indicate their role in spreading of epidemiologically significant species.

\section{MATERIAL AND METHOD}

The biodiversity of aquatic organisms of 6 fountains in Prešov (Eastern Slovakia, population cca 90 000, without big industry) was studied during 2014 (Figure 1). For coordinates, water volume and distance to the closest bigger water source, i.e., Torysa River, see Table 1 . The studied urban fountains operate yearly from April to October. During winter, they are without water. Each of studied fountains was completely drained, cleaned and water chemically adjusted at monthly intervals (usually within 24 hours).

Basic environmental parameters, such as $\mathrm{pH}$, temperature, oxygen saturation and electrical conductivity $\left(25^{\circ} \mathrm{C}\right)$, were measured in the field twice, at the beginning and the end of June, using a Multi 3401i (WTW). The average values (average value of different date measurements) of the measured parameters are shown in the Table 2. Comparison of measured parameters among studied fountains showed variation in conductivity $(568 \sim 1086 \mu \mathrm{S} /$ $\mathrm{cm})$, oxygen saturation $(9.25-18.65 \mathrm{mg} / \mathrm{l})$, water temperature $\left(12.5-23.7^{\circ} \mathrm{C}\right)$ and water $\mathrm{pH}(7.2-8.61)$. Water depth varied between $10-30 \mathrm{~cm}$ and water volume between 1.9 to $51 \mathrm{~m}^{3}$. The total amount of sampling effort was equal

Table 1. Basic characteristics of the urban fountains.

\begin{tabular}{|c|c|c|c|c|c|}
\hline$\stackrel{.}{\circ}$ & 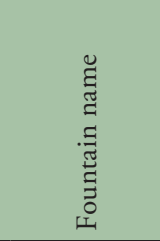 & 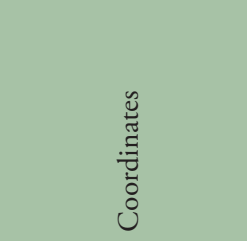 & 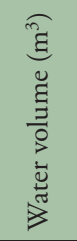 & 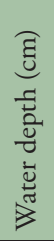 & 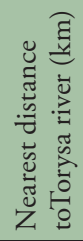 \\
\hline 1. & Divízia & $\begin{array}{l}\text { N } 48^{\circ} 59^{\prime} 33.2946^{\prime \prime} \\
\text { E } 21^{\circ} 14^{\prime} 41.967^{\prime \prime}\end{array}$ & 40.5 & 30 & 0.85 \\
\hline 2. & Neptún & $\begin{array}{l}\text { N } 48^{\circ} 59^{\prime} 50.1^{\prime \prime} \\
\text { E } 21^{\circ} 14^{\prime} 26.091^{\prime \prime}\end{array}$ & 7.2 & 20 & 0.65 \\
\hline 3. & $\begin{array}{l}\text { Velká } \\
\text { fontána (A) }\end{array}$ & $\begin{array}{l}\text { N 49 } 0^{\circ} 0^{\prime} 6.1122^{\prime \prime} \\
\text { E } 21^{\circ} 14^{\prime} 22.8876^{\prime \prime}\end{array}$ & 7.2 & 30 & 0.73 \\
\hline 4. & $\begin{array}{l}\text { Velká } \\
\text { fontána (B) }\end{array}$ & $\begin{array}{l}\text { N } 49^{\circ} 0^{\prime} 6.2388^{\prime \prime} \\
\text { E } 21^{\circ} 14^{\prime} 25.2024^{\prime \prime}\end{array}$ & 1.9 & 10 & 0.75 \\
\hline 5. & Družba & $\begin{array}{l}\text { N } 49^{\circ} 0^{\prime} 23.292^{\prime \prime} \\
\text { E } 21^{\circ} 13^{\prime} 26.3028^{\prime \prime}\end{array}$ & 51 & 30 & 0.24 \\
\hline 6. & Centrál & $\begin{array}{l}\text { N } 48^{\circ} 59^{\prime} 55.2948^{\prime \prime} \\
\text { E } 21^{\circ} 13^{\prime} 28.2714^{\prime \prime}\end{array}$ & 12.6 & 10 & 0.4 \\
\hline
\end{tabular}


Table 2. The average values (with SD) of the environmental water parameters.

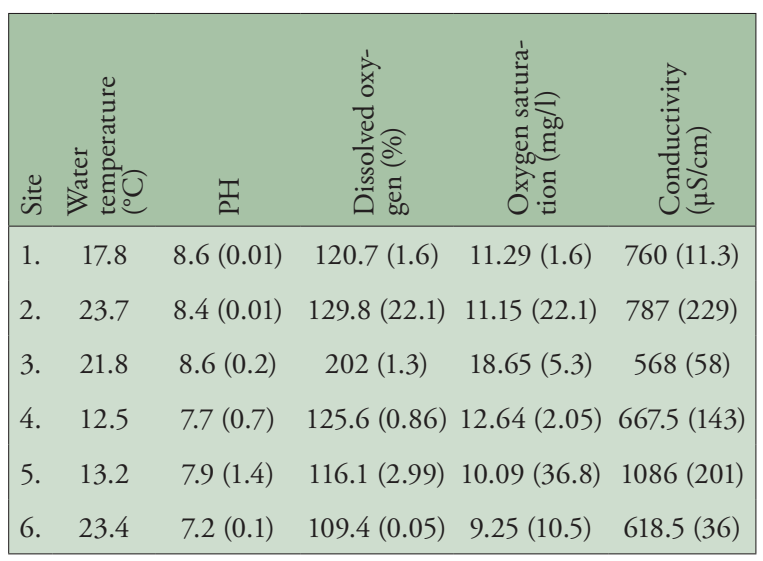

in all the sites $(1 \mathrm{~min})$. Insects were collected by kicking technique using D-shaped hand net (mesh size $0.2 \mathrm{~mm}$ ) (8), at monthly intervals from May to October (except August), transported to laboratory, preserved in 75\% ethanol and then identified to the lowest possible taxonomic level, using general and specialized keys for benthic macroinvertebrates $(9,10,11,12)$. Some pupae and larvae of the family Ceratopogonidae were reared to an adult stage according to Oboňa \& Dominiak (13). The material examined is deposited in the Laboratory and Museum of Evolutionary Ecology, University of Prešov, except biting midges (deposited in the Department of Invertebrate Zoology and Parasitology, University of Gdańsk, Poland) and non-biting midges (deposited in the Department of Hydrobiology, Microbiology and Ecotoxicology, Water Research Institute, Bratislava, Slovakia).

Table 3. List of non-insect taxa from urban fountains ( $J=J u n e$ and $O=O c t o b e r)$.

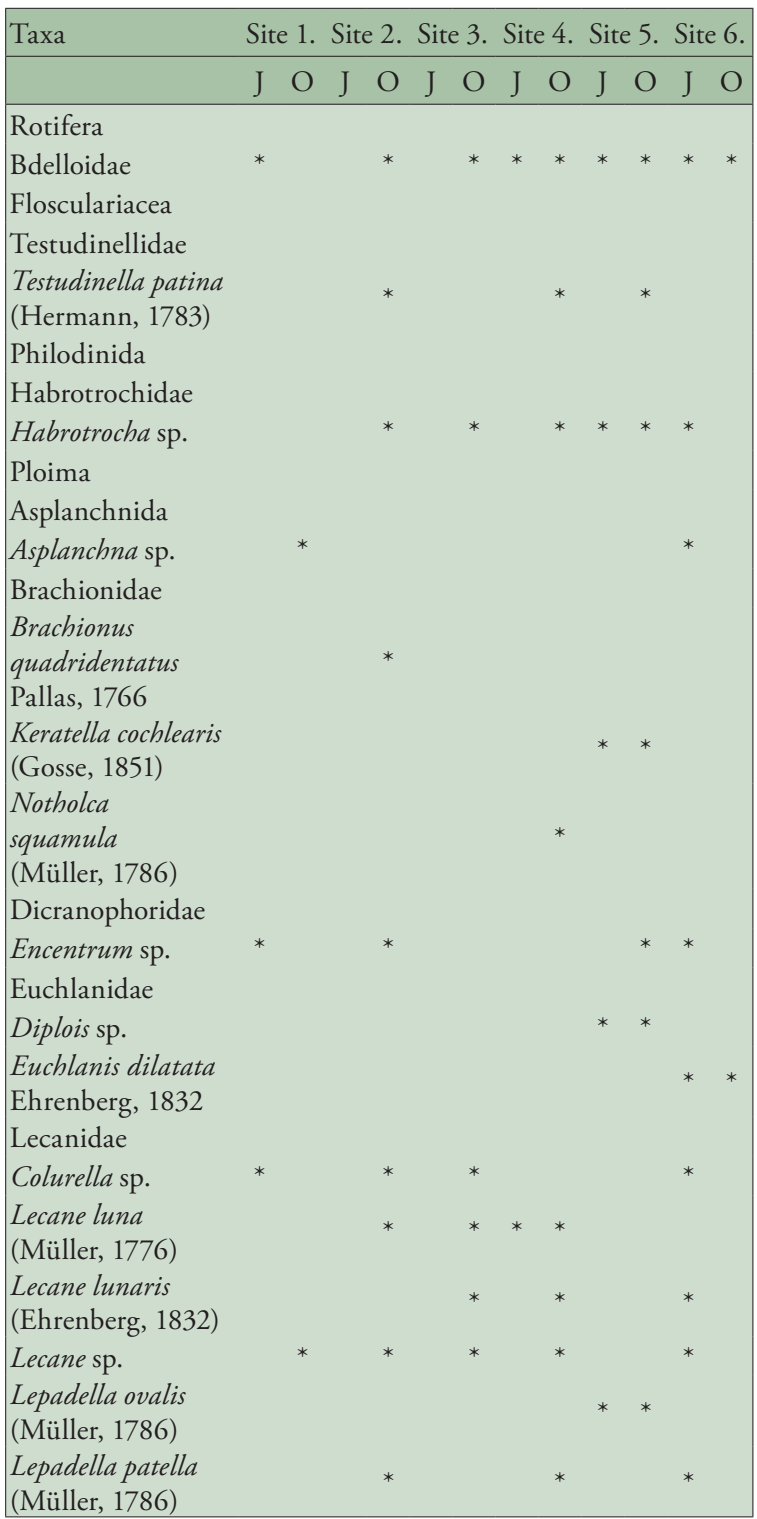

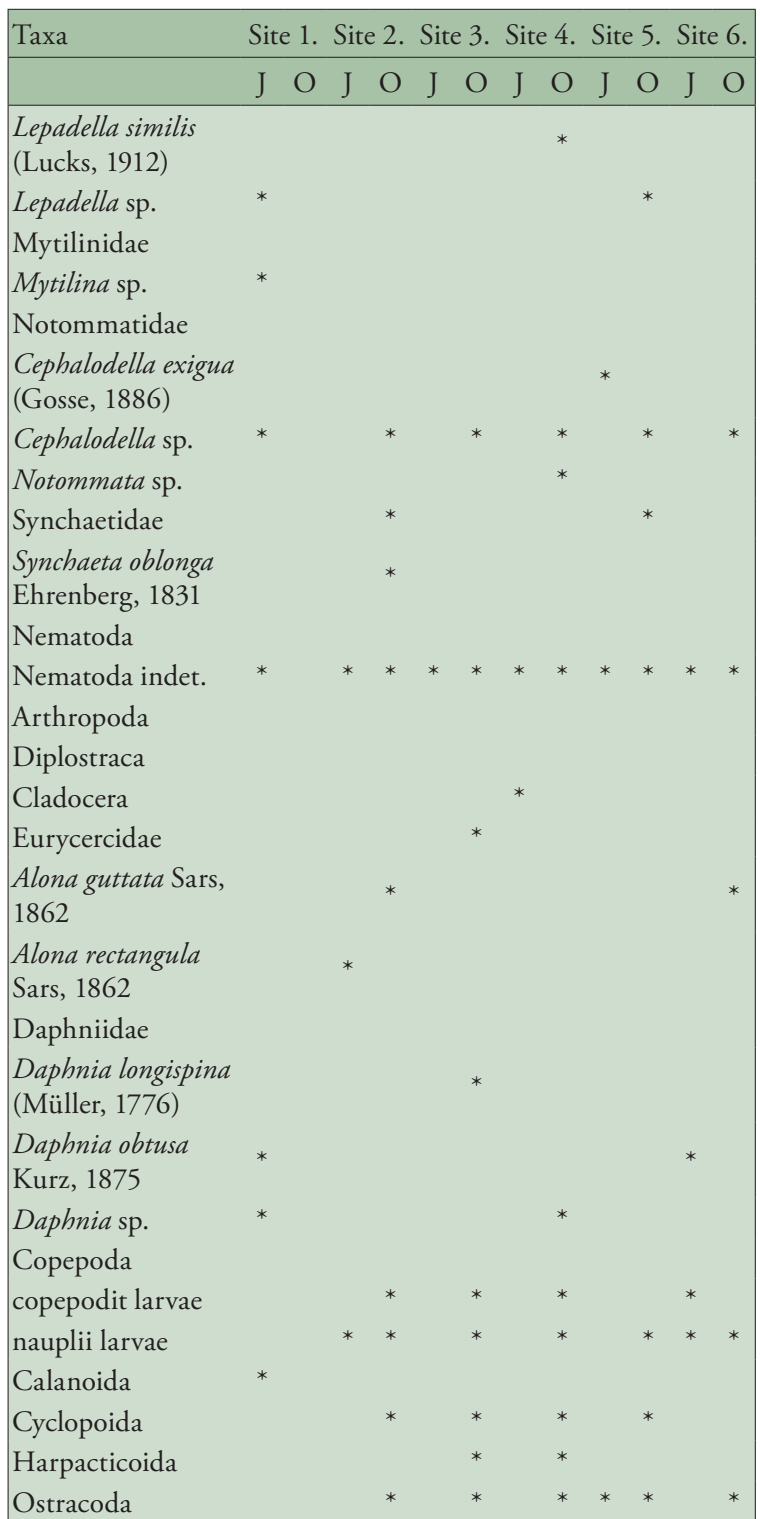




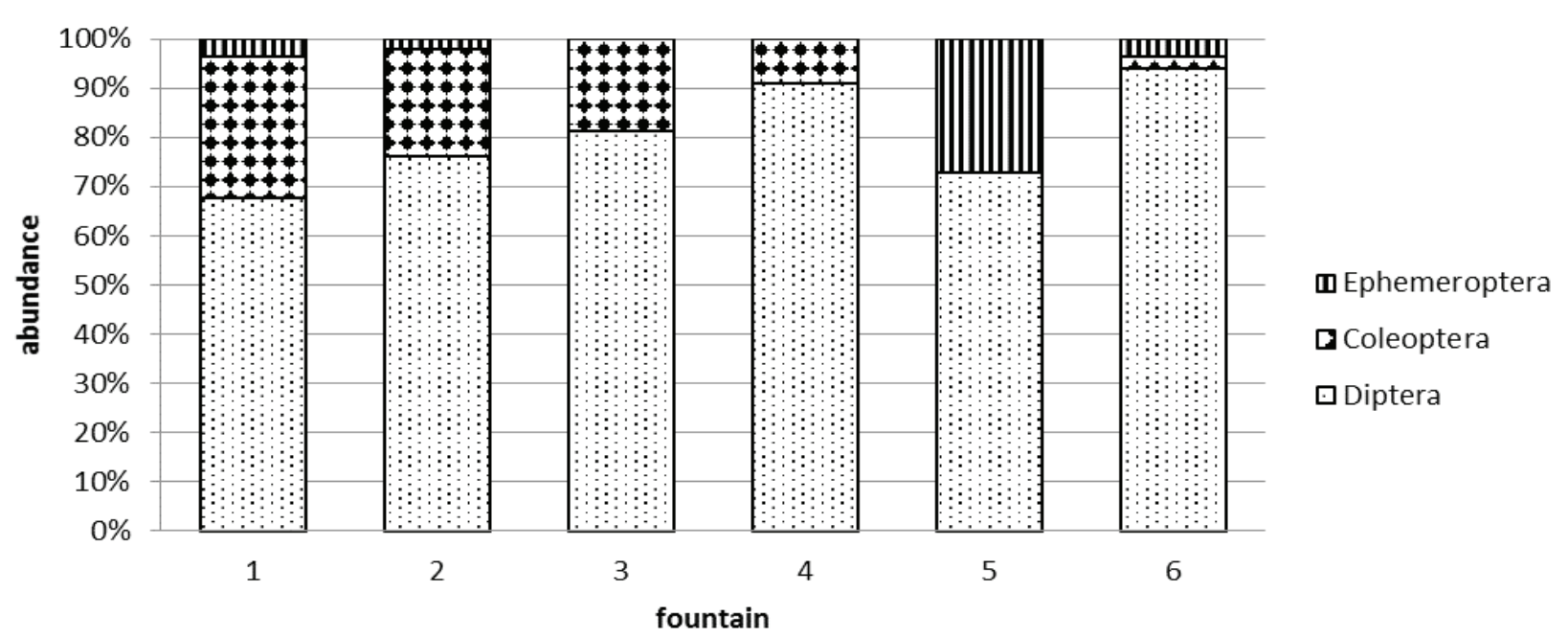

Figure 2. The specimen percentage abundance of dominant insect orders in 6 sampled fountains.

Zooplankton samples were collected twice from each fountain in June and October. The samples (20 litres for each fountain) were filtered through the plankton net on $0.5 \mathrm{~m}$ long handle with $90 \mu \mathrm{m}$ mesh size $(25 \mathrm{~cm}$ diameter). The zooplankton was collected in a net micro-bucket of 50 $\mathrm{mls}$ and transferred into plankton bottles and fixed with $70 \%$ ethanol. Samples were identified using a microscope according to several identification keys $(14,15,16,17)$.

Friedman's Rank Sum test (18) was used to test temporal differences in taxonomic richness and water parameters. In order to test differences in taxonomic richness between 6 evaluated fountains, non-parametric Kruskal-Wallis test (19) was used. Spearman's correlation coefficient was used to test relationships significance between water characteristics and relative abundance of insects specimens at three taxonomic levels (order, family and species).

\section{RESULTS}

\section{Community composition}

No significant differences $(\mathrm{P}=0.95)$ among fountains in specimen abundance was found. In total, 66 taxa of the phyla Rotifera, Nematoda and Arthropoda (Cladocera, Copepoda, Ostracoda and Insecta: Coleoptera, Diptera, Ephemeroptera, Heteroptera) were found in the studied fountains (see list of taxa - Table 3, Table 4 and Figure 2)

As many as 410 insect specimens were collected in the fountains, belonging to 4 orders, 7 families and 28 species/taxa (Table 4). The Diptera with 349 identified specimens represent the most abundant order, followed by Coleoptera (46 specimens), Ephemeroptera (12 specimens) and Heteroptera (3 specimens). The relative abun-

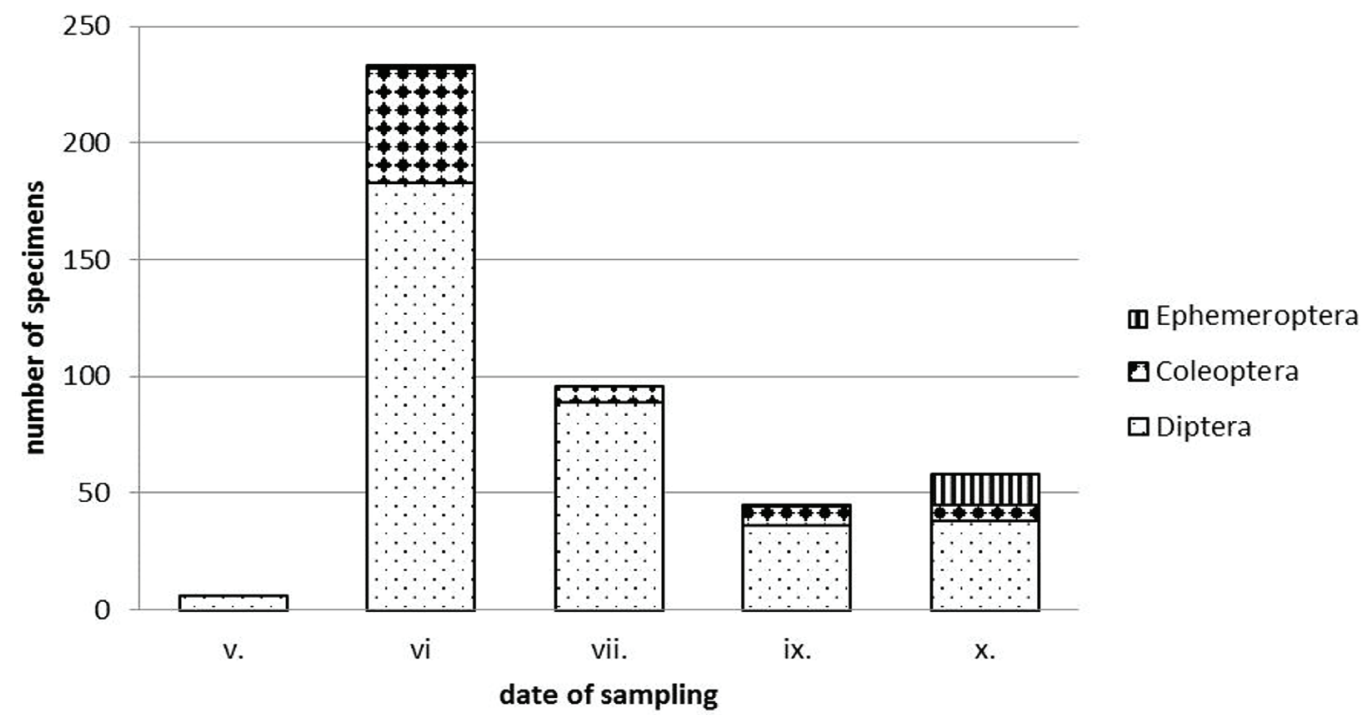

Figure 3. The specimen abundance of dominant insect orders depending on the sampling date. 
Table 4. List of insect taxa from urban fountains with presence in sampling periods.

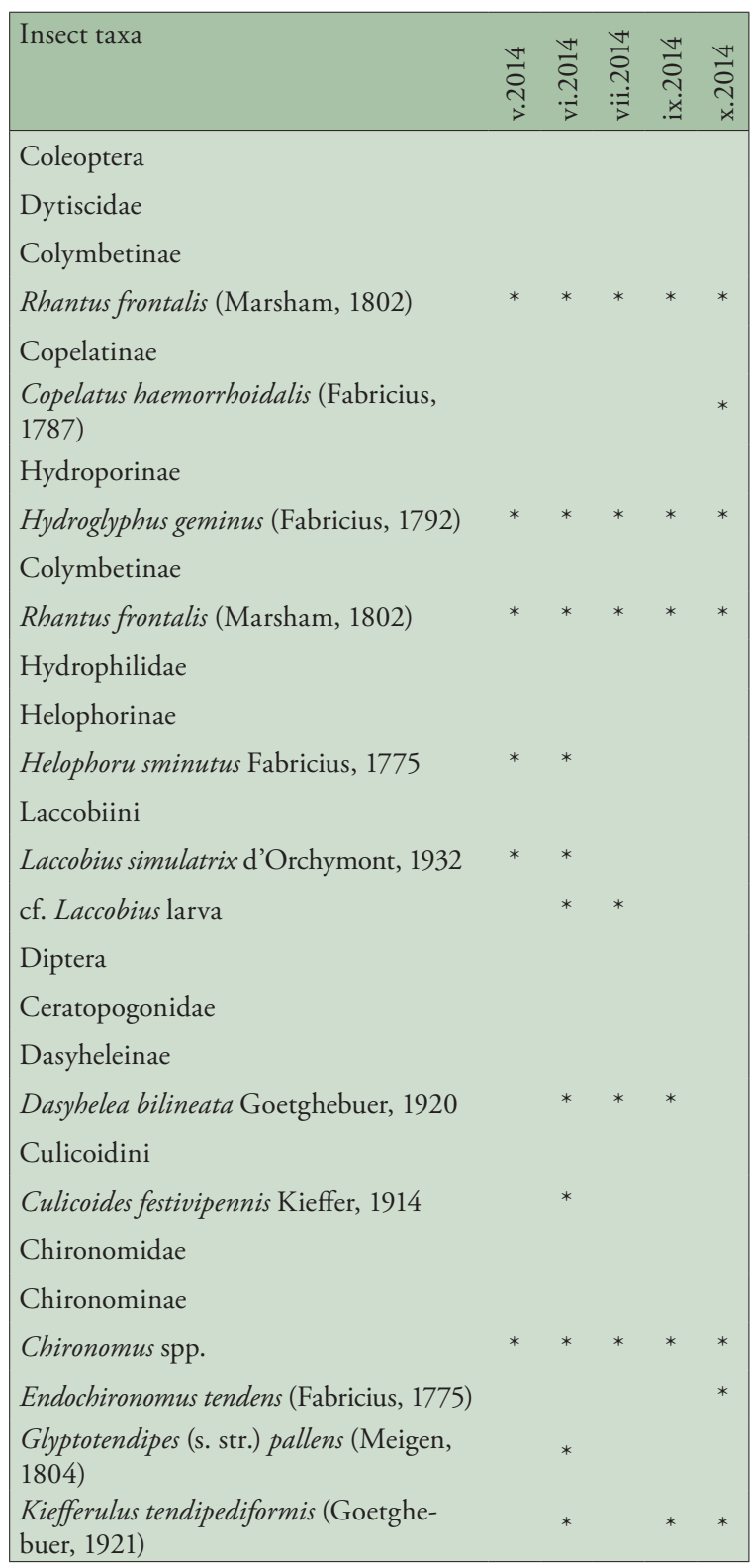

dance of the insect orders (Coleoptera, Diptera, Ephemeroptera and Heteroptera) across 6 fountains are presented in Figure 2. Samples were dominated by $\mathrm{Chi}$ ronomus spp. (25\%), Dasyhelea bilineata (13\%), Psectrocladius limbatellus (11\%), Culex pipiens (9\%), Orthocladius (Eudactylocladius) fuscimanus (7.5\%), Cricotopus (Isocladius) sylvestris (5\%), Anopheles maculipennis (5\%) species. Another 18 taxa were represent by $0.2-4.6 \%$ portion. The larvae and pupae of the family Chironomidae were present in almost every fountain. Zavrelimyia nubila (Diptera: Chironimidae) was recorded in Slovakia for the first time. The non-insect fauna was represented by 38 identified taxa (Table 3). Among Rotifera (23 taxa, 9 families), most abundant and with highest frequency of occurrence in fountains were the family Bdelloidae and

\begin{tabular}{|c|c|c|c|c|c|}
\hline Insect taxa & 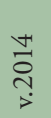 & $\begin{array}{l}\stackrel{+}{*} \\
\stackrel{i}{1} \\
\stackrel{5}{7}\end{array}$ & 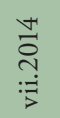 & 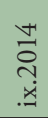 & $\underset{\stackrel{\leftrightarrow}{\sim}}{\stackrel{\leftrightarrow}{x}}$ \\
\hline \multicolumn{6}{|l|}{ Orthocladiinae } \\
\hline Acricotopus lucens (Zetterstedt, 1850) & * & & * & & \\
\hline $\begin{array}{l}\text { Cricotopus (Isocladius) sylvestris (Fabri- } \\
\text { cius, 1794) }\end{array}$ & & * & * & * & \\
\hline $\begin{array}{l}\text { Orthocladius (Eudactylocladius) fuscima- } \\
\text { nus (Kieffer, 1908) }\end{array}$ & * & * & * & & \\
\hline $\begin{array}{l}\text { Psectrocladius (s. str.) limbatellus (Hol- } \\
\text { mgren, 1869) }\end{array}$ & & * & * & & * \\
\hline Thienemanniella sp. & & & & & $*$ \\
\hline Tanytarsinae & & & & & \\
\hline Micropsectra notescens (Walker, 1856) & & & & & * \\
\hline Tanytarsus sp. & & & & * & \\
\hline Tanypodinae & & & & & \\
\hline Zavrelimyia barbatipes (Kieffer, 1911) & & & * & * & * \\
\hline Zavrelimyia nubile (Meigen, 1830) & & & & & * \\
\hline Zavrelimyia sp. & & & & & * \\
\hline Culicidae & & & & & \\
\hline Anophelinae & & & & & \\
\hline $\begin{array}{l}\text { Anopheles maculipennis s.l. Meigen, } \\
1818\end{array}$ & & * & * & * & \\
\hline Culicinae & & & & & \\
\hline Culex pipiens Linnaeus, 1758 & * & * & * & * & \\
\hline Ephemeroptera & & & & & \\
\hline Baetidae & & & & & \\
\hline Baetidae & & & & & \\
\hline Cloeon dipterum (Linnaeus, 1761) & & & & * & * \\
\hline Heteroptera & & & & & \\
\hline Corixidae & & & & & \\
\hline Corixinea & & & & & \\
\hline Sigara nigrolineata (Fieber, 1848) & & * & & & \\
\hline Sigara lateralis (Leach, 1817) & & & & & * \\
\hline
\end{tabular}

the genera Habrotrocha and Cephalodella. Nematodes were present in all fountains. Cladocera occurred in these water bodies only sporadically, but Copepoda have a greater frequency of occurrence. Relatively common, especially in samples from October, were Ostracoda.

\section{Taxonomic composition of insect fauna}

The presence of studied insect taxa differed depending on the sampling date (Figure 3), but was also influenced by the water characteristics. Correlations between fountain water characteristics and relative abundance of insect taxa are presented in Table 5. Significant positive correlation $(\mathrm{P}<0.05)$ was found between dates (from May to October) and the relative abundance of Zavrelimyia sp., 
Kiefferulus tendipediformis and Cloeon dipterum. On the contrary, decreasing abundance of taxa with increasing sampling period was reported for D. bilineata, Laccobius simulatrix and Helophorus minutus. Water volume and water depth negatively $(\mathrm{P}>0.06)$ correlated with abundance of all evaluated orders. The higher water depth significantly negatively influenced the abundance of Psectrocladius limbatellus $(\mathrm{P}<0.05)$ and $C$. pipiens $(\mathrm{P}<0.01)$. Water $\mathrm{pH}$ was significantly positively related only with abundance of Coleoptera. At the family level, $\mathrm{pH}$ impacted positively with the abundance of the family $\mathrm{Hy}$ drophilidae $(\mathrm{P}<0.05)$. In general, the abundance of Diptera and Ephemeroptera correlated negatively $(\mathrm{P}>0.06)$ with water $\mathrm{pH}$. When considering species level, increasing $\mathrm{pH}$ have significant positive influence on abundance of $D$. bilineata $(\mathrm{P}<0.05)$ and significantly negative influence on abundance of $C$. pipiens $(\mathrm{P}<0.01), P$. limbatellus $(\mathrm{P}<0.05)$, and $A$. maculipennis $(\mathrm{P}<0.01)$.

Many insects were present in fountains in almost all samples throughout the season (e.g. Chironomus spp., $\mathrm{Hy}$ droglyphus geminus, see Table 4), but some taxa (e.g. Acricotopus lucens, $H$. minutus) have shown tendency to colonize fountains at the beginning of their operation (May-June). On the contrary, some taxa (e.g. Endochironomus tendens, Micropsectra notescens and C. dipterum) tend to colonize the fountains at the end of the season (September-October).

\section{DISCUSSION}

Artificial water bodies are generally known to support lower species richness than natural ponds, and their physicochemical environment is harsher as well $(20,21,22)$. In urban areas, anthrotelmata represent refuges for dispersing aquatic or semi-aquatic organisms. Hence, the fountain habitat seems to be a unique urban aquatic environment with insect communities formed mainly by species from surrounding natural water bodies. Oboňa et al. (23) studied small temporary rain pools in Upper Nitra region (Slovakia) and found relatively different insect community except perhaps $C$. pipiens. However, these small anthrotelmata had a completely different substrate (loam, leaf litter or plant roots), which is not present in fountains. Rieradevall \& Cambra (24) studied urban freshwater ecosystems in Barcelona and found that character of the substrate as well as size of the water body influence colonization of urban waters. The urban fountains are anthrotelmata with limited resources, and that could at least partly explain why different taxa colonize these habitats in different seasons. At the beginning of the fountain life (May), only minimum resources were present in the fountain (e.g. pollution from urban air, soils). In summer (July, August), due to sunlight, the fountains often turned green due to the growth of algae, and at the end of the fountain sprinkling period (September, October) due to frequent fell, wind transport of organic particles and leaf litter from the surrounding. Each season can be therefore characterized by different resource base, to which can reflect on presence of different groups of insect. Although the fountains were cleaned every month, the initial results suggest the possibility of functioning of the seasonal variability.

Despite their high dependence on natural colonization sources of insects, artificial urban water bodies do not seem to be only reflection of the status of surrounding water bodies. Instead of this, they probably could contribute to the regional biodiversity (25).

Study of Holland \& Jenkins (26) indicates that local conditions (habitat permanence and resource availability) has the greatest effect on zooplankton species richness. Comparison of cumulative species richness shows a significant reduction of species richness in temporary treatments compared to permanent ones. Cumulative species richness was not significantly affected by nutrient enrich-

Table 5. Significant correlation relationship between fountain water characteristics and relative abundance of insect taxa

\begin{tabular}{|c|c|c|c|c|c|c|c|c|c|c|c|}
\hline & 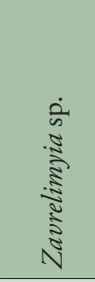 & 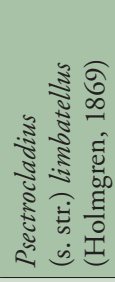 & 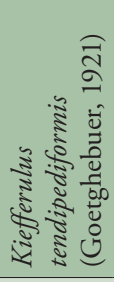 & 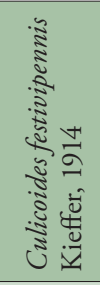 & 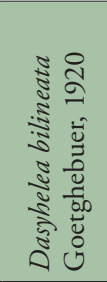 & 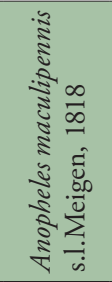 & 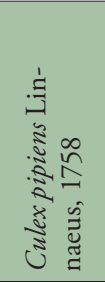 & 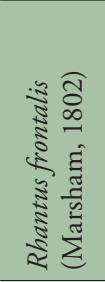 & 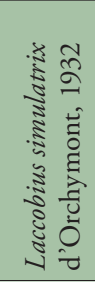 & 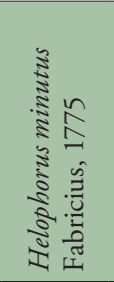 & 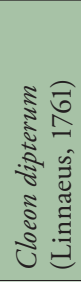 \\
\hline \multicolumn{12}{|l|}{ water volume $\left(\mathrm{m}^{3}\right)$} \\
\hline water depth $(\mathrm{cm})$ & & $-0.45^{*}$ & & $-0.58^{* *}$ & & & & & & & \\
\hline $\mathrm{pH}$ & & $-0.42^{*}$ & & & $0.37^{*}$ & $-0.49^{* *}$ & $-0.47^{* *}$ & & & & \\
\hline oxygen saturation $(\mathrm{mg} / \mathrm{l})$ & $0.36^{*}$ & & & & & $-0.36^{*}$ & & & & & \\
\hline conductivity $(\mu \mathrm{S} / \mathrm{cm})$ & $-0.39^{*}$ & $-0.41^{*}$ & & & & & & & & & \\
\hline nearest distance to Torysa river $(\mathrm{km})$ & $0.38^{*}$ & & & & $0.48^{* *}$ & & & $-0.47^{* *}$ & & & \\
\hline date & $0.44^{*}$ & & $0.37^{*}$ & & -0.41 & & & & $-0.36^{*}$ & $-0.37^{* *}$ & $0.42^{*}$ \\
\hline
\end{tabular}


ment. Similarly, drying has the greatest effect on colonization curves, or species richness through time. Zooplankton occurence in all sampling sites, even after short time after fountain draining and cleaning, indicates high dispersalability in all zooplanktonic groups (Cladocerans, Copepods and Rotifers) in a short period of time.

Our study affirms Frisch et al. (27) finding about colonization rates. Based on cumulative species richness colonization rate differed between zooplankton taxa according to which rotifers are the fastest and copepods the slowest colonizators. Most probably, copepods as obligate sexuals, may show delayed colonization due to a stronger Allee effect compared to cyclical parthenogens, such as rotifers and cladocerans. During present studies, we recorded 23 rotifera and 4 cladoceran taxons mostly in adult stage in contrary to mostly unidentified juvenile copepods.

The studied fountains showed high oxygen content, variation in conductivity, temperature and $\mathrm{pH}$ (from slightly acidic to slightly alkaline water). The loss of water and completely cleaning of these habitats in general cause a potential catastrophic event on aquatic insects. However, some species (e.g. larvae of the families Chironomidae and Ceratopogonidae) are able to persist cleaning cycles and were found in fountains immediately after filling with water. Some insects of anthrotelmata exhibit traits of r-selected species, especially high power of dispersal, rapid growth, short life-span, small size, opportunistic/generalistic feeding and poor competitive capabilities (28). Apparently, these taxa are probably most common and the most successful insects colonizers of strictly seasonal urban aquatic fountains. However, not only the environmental conditions, but also spatial configuration determines the species composition of aquatic habitats (29), and moreover, the surrounding colonization sources play a key role in community structure of temporary water bodies (20). According to our findings, the distance to Torysa River has been not significantly limiting factor for evaluated taxa. We assume that these ecosystems are probably colonized from small temporary water bodies from surrounding. However, Hamerlík \& Brodersen (6) suppose that the distance to river source has probably also impact on fountain colonization.

Urban fountains in Prešov are also occupied by epidemiologically significant species. During our studies two species of mosquitoes were recorded, these are $C$. pipiens and $A$. maculipennis, as well as one haematophagous species belonging to biting midges, namely Culicoides festivipennis. Becker et al. (12) summarized the variability of mosquito-borne diseases. According to this paper (12), mosquitoes occuring in fountains are potential vectors of various viruses, e.g. the West Nile virus transmitted by $C$. pipiens or by $A$. maculipennis the Batai virus (strain: Calovo virus) transmitted by $A$. maculipennis (30), or Sindbis virus, which was isolated from $C$. pipiens $(31,32)$. Biting midge $C$. festivipennis is host generalists $(33,34,35,36$, $37,38)$, attacking different groups of vertebrates, and thus, this species can facilitate the emergence of new diseases (39).

Our studies on urban fountains are preliminary ones and for sure it is necessary to examine these ecosystems more carefuly.

Acknowledgements: This study was supported by the Slovak Research and Development Agency under the contract No. APVV-0059-11 and by project VEGA-2/0030/17.

\section{REFERENCES}

1. WILLIAMS DD 2006 The Biology of Temporary Waters. Oxford University Press. p. 347

2. SEMIDOR C, VENOT-GBEDJI F 2009 Outdoor Elements Providing Urban Comfort: The role of fountains in the soundscape. PLEA2009 - 26th Conference on Passive and Low Energy Architecture, Quebec City, Canada, 22-24 June 2009

3. SMOLÁK R, OBOŇA J, ŠČERBÁKOVÁ S 2014. Urban fountains, overlooked temporal aquatic ecosystems? p. 204 In: MANKO P, BARANOVÁ B. (eds.) Zborník príspevkov z vedeckého kongresu „Zoológia 2014“, 19. Feriancové dni, Prešov, 20.-22 november 2014. Prešovská univerzita v Prešove.

4. SCHAFFNER F, KAUFMANN C, HEGGLIN D, MATHIS A 2009 The invasive mosquito Aedes japonicus in Central Europe. Medical and Veterinary Entomology 23: 448-451 https://doi.org/10.1111/j.1365-2915.2009.00825.x

5. HAMERLÍK L 2007 Chironomidae (Diptera) from fountains new for Czech Republic. Lauterbornia 61:137-140

6. HAMERLÍK L, BRODERSEN KP 2010 Non-biting midges (Diptera: Chironomidae) from fountains of two European cities: micro-scale island biogeography. Aquat Insects 32(1): 67-79 https://doi.org/10.1080/01650420903397645

7. BUKVOVÁ D, HAMERLÍK L 2015 Non-biting midges (Diptera, Chironomidae) in the fountains of Lund, SW Sweden. [Fjädermyggor i föntäner i Lund] Entomologisk Tidskrift 136(3): 87-92

8. FROST S, HUNI A, KERSHAW WE 1971 Evaluation of a kicking technique for sampling stream bottom fauna. Canadian Journal of Zoology 49(2): 167-173 https://doi.org/10.1139/z71-026

9. ROZKOŠNÝ R 1980 Klíč vodní chlarev hmyzu, Academia, Praha. p. 519

10. NILSSON AN 1997 Aquatic Insects of North Europe: A Taxonomic Handbook. Odonata-Diptera, Volume 2. Apollo Books: Stenstrup, Denmark. p. 440

11. LANGTON PH 1991 A key to pupal exuviae of WestPalaearctic Chironomidae. Private publication. Langton PH, 3, St. Felix Road, Ramsey Forty Foot, Huntingdon, Cambridgeshire. England PE17 1YH. p. 324

12. BECKER N, PETRIC D, ZGOMBA M, BOASE C, DAHL C, LANE J, KAISER A 2003 Mosquitoes and their control. Kluwer Academic / Plenum Publisher, New York. p. 498 https://doi.org/10.1007/978-1-4757-5897-9

13. OBOŇA J, DOMINIAK P 2014 Biting midges (Diptera: Ceratopogonidae) in tree hole habitats in Slovakia. Oceanological and Hydrobiological Studies 43: 61-65 https://doi.org/10.2478/s13545-014-0118-y

14. BARTOŠ E 1959 Víŕnici - Rotatoria, Fauna ČSR, Nakladatelství ČSAV, Praha. p. 969

15. ŠRÁMEK-HUŠEK R 1953 Naši klanonožci, Nakladatelstí ČSAV, Praha. p. 245

16. ŠRÁMEK-HUŠEK R, STRAŠKRABA M, BRTEK J 1962 Fauna ČSSR, svazek 16. Lupenonožci - Branchiopoda. Nakladetlství ČSAV, Praha. p.472 
17. KOTOV AA 2013 Morphologhy and phylogeny of the Anomopoda (Crustacea: Cladocera). Association scientific journals KMK, Moscow. p. 638

18. FRIEDMAN M 1937 The use of ranks to avoid the assumption of normality implicit in the analysis of variance. Journal of the American Statistical Association. American Statistical Association. 32 (200): 675-701 https://doi.org/10.1080/01621459.1937.10503522

19. KRUSKAL W, WALLIS WA 1952 Use of ranks in one-criterion variance analysis. Journal of the American Mathematical Society 47(260): 583-621. https://doi.org/10.1080/01621459.1952.10483441

20. WILLIAMS DD 1996 Environmental constraints in temporary fresh waters and their consequences for the insect fauna. Journal of the North American Benthological Society 15(4): 634-650 https://doi.org/10.2307/1467813

21. WOOD PJ, GREENWOOD MT, BARKER SA, GUNN J 2001 The effects of amenity management on the conservation value of aquatic invertebrate communities in old industrial pools. Biological Conservation 102: 17-29 https://doi.org/10.1016/S0006-3207(01)00087-8

22. WILLIAMS P, WHITFIELD M, BIGGS J, BRAY S, FOX G, NICOLET P, SEAR D 2003 Comparative biodiversity of rivers streams, ditches and ponds in an agricultural landscape in Southern England. Biological Conservation 115: 329-341 https://doi.org/10.1016/S0006-3207(03)00153-8

23. OBOŇA J, DOMINIAK P, MATUŠOVÁ Z, ŠČERBÁKOVÁ S, SVITOK M 2014 Invertebrate fauna of small temporary rain pools of village Diviacka NováVes (Upper Nitra region - Slovakia). Folia Oecologica 6: 23-30

24. RIERADEVALL M, CAMBRA J 1994 Urban freshwater ecosystems in Barcelona. Verhandlungen Internationale Vereinigung für Theoretische und Angewandte Limnologie 25: 1369-1372

25. HAMERLÍK L, JACOBSEN D, BRODERSEN KP 2011 Low species richness of non-biting midges (Diptera: Chironomidae) in Neotropical artificial urban water bodies. Urban Ecosystem 14: 457-468 https://doi.org/10.1007/s11252-011-0163-x

26. HOLLAND T A, JENKINS D G 1998 Comparison of processes regulating zooplankton assemblages in new freshwater pools. Hydrobiologia 387/388: 207-214. https://doi.org/10.1023/A:1017093810178

27. FRISCH D, COTTENIE K, BADOSA A, GREEN AJ 2012 Strong Spatial Influence on Colonization Rates in a Pioneer Zooplankton Metacommunity. PLoS ONE 7(7): e40205. https://doi.org/10.1371/journal.pone.0040205
28. MCLACHLAN A 1993 Can two species of midge coexist in a single puddle of rain-water? Hydrobiologia 259: 1-8 https://doi.org/10.1007/BF00005959

29. VERBERK WCEP, VAN DUINEN GA, BROCK AMT, LEUVEN RSEW, SIEPEL H, VERDONSCHOT PFM, VAN DER VELDE G, ESSELINK H 2006 Importance of landscape heterogeneity for the conservation of aquatic macroinvertebrate diversity in bog landscapes. Journal for Nature Conservation 14: 78-90 https://doi.org/10.1016/j.jnc.2005.11.002

30. BARDOS V, CUPKOVA B 1962 The Calovo virus - the second virus isolated from mosquitoes in Czechoslovakia. Journal of hygiene, epidemiology, microbiology, and immunology 6: 186-192

31. FRANCY DB, JAENSON TGT, LUNDSTRÖM JO, SCHILDT EB, ESPMARK A, HENRIKSSON B, NIKLASSON B 1989 Ecologic studies of mosquitoes and birds as hosts of Ockelbo virus in Sweden, and isolation of Inkoo and Batai viruses from mosquitoes. The American Journal of Tropical Medicine and Hygiene 41: 355-363

32. LUNDSTRÖM JO 1994 Vector competence of western European mosquitoes for arboviruses: A review of field and experimental studies. Bulletin of the Society for Vector Ecology 19: 23-36

33. PACLT J, CALLOT J, KREMER M 1970: Cératopogonidés piqueurs habitant les tourbiéreset les biotopes non-tourbeux de la partie supérieure d'orava (Diptera Nematocera). Biológia (Bratislava) 25: 751-759

34. ORSZAGH I 1976 Die Gattung Culicoides Latr. 1809 (Diptera, Ceratopogonidae) in Slowakei. Acta Facultatis Rerum Naturalium Universitatis Comenianae-Zoologia 21: 1-88

35. KREMER M 1965 Contribution aletude du genre Culicoides Latreille, particulie rementen France. Editions P. Lechevalier Paris. Encyclopédie Entomologique Série A 39:3-299

36. BURYLOVA AM 1975 On blood sucking midges attacking the birds in the forests of Prikamje. Parazitologiya 9: 197-200

37. NIELSEN OB 1964 Studies on the Danish biting midges, Culicoides Latreille (Dipt., Ceratopogonidae). Entomlogiske Meddele1ser 32: 261-276

38. BENNETT GF 1960 On some ornithophilic blood-sucking diptera in the Algonquin Park, Ontario, Canada. Canadian Journal of Zoology 38:377-389 https://doi.org/10.1139/z60-042

39. SANTIAGO-ALARCON D, HAVELKA P, SCHAEFER HM, SEGELBACHER G 2012 Blood meal analysis reveals avian Plasmodium infections and broad host preferences of Culicoides (Diptera: Ceratopogonidae) vectors. PLoS ONE 7, e31098 https://doi.org/10.1139/z60-042 